\title{
ORGANOTROPISM OF ORGANIC AND INORGANIC MERCURY IN FISH FROM THE VISTULA LAGOON, POLAND*
}

\author{
Lucyna Polak-Juszczak, Agnieszka Góra \\ Department of Food and Environmental Chemistry \\ National Marine Fisheries Research Institute, Gdynia, Poland
}

\begin{abstract}
Our paper presents the results of a study on the concentrations of total $\left(\mathrm{Hg}_{\text {total }}\right)$, organic $\left(\mathrm{CH}_{3} \mathrm{Hg}^{+}\right)$ and inorganic $\left(\mathrm{Hg}_{\text {inorg }}\right)$ mercury in freshwater fish from the Vistula Lagoon, coastal waters of the Baltic Sea. Mercury assays were performed on tissues (muscle, skin, gills) and internal organs (heart, spleen, liver, gastrointestinal tract, gonads) of pikeperch, common roach, and common bream. The distributions of $\mathrm{Hg}_{\text {total }}, \mathrm{CH}_{3} \mathrm{Hg}^{+}$, and $\mathrm{Hg}_{\text {inorg }}$ depending on fish species, tissue, or organ and bioaccumulation in tissues and biomagnification in the trophic chain were determined. Interspecific and intraspecific differences in mercury concentrations occurred in fish tissues and organs. Muscles of pikeperch, bream and roach accumulated the highest concentration of $\mathrm{CH}_{3} \mathrm{Hg}^{+}, \mathrm{Hg}_{\text {inorg }}$ dominating in the gastrointestinal tract of bream and roach. The concentration gradations of $\mathrm{Hg}_{\text {total }}$ and $\mathrm{CH}_{3} \mathrm{Hg}^{+}$depending on fish species were as follows: pikeperch > common roach $>$ common bream. For $\mathrm{Hg}_{\text {inorg }}$, the gradations were as follows: common bream $>$ common roach $>$ pikeperch. The type of food was a determining criterion for the distribution of mercury forms in the tissues and organs of the fish studied, and quantifiable confirmation of this was the different values of the $\mathrm{L}: \mathrm{M}$ coefficient $\left(\mathrm{Hg}_{\text {inorg }}\right.$ in the hepatic tissue : $\mathrm{CH}_{3} \mathrm{Hg}^{+}$in muscle). Differences in $\mathrm{Hg}_{\text {total }}, \mathrm{CH}_{3} \mathrm{Hg}^{+}$, and $\mathrm{Hg}_{\text {inorg }}$ concentrations in fish tissues and organs were linked with the food the fish consume, their position in the trophic chain and biomagnification in the food chain.
\end{abstract}

Keywords: freshwater fish, organic, inorganic mercury, bioaccumulation, biomagnification.

dr hab. Lucyna Polak-Juszczak, prof. nadzw. National Marine Fisheries Research Institute, Department of Food and Environmental Chemistry, Kollataja 1, Gdynia 81-332, Poland, e-mail: lpolak@mir.gdynia.pl

* This study was performed as part of a statutory research project financed by the Polish Ministry of Science and Higher Education. 


\section{INTRODUCTION}

In aquatic environments mercury occurs mainly in inorganic compounds, which through methylation are transformed into the organic form of mercury, methylmercury $\left(\mathrm{CH}_{3} \mathrm{Hg}^{+}\right) .\left(\mathrm{CH}_{3} \mathrm{Hg}^{+}\right)$. The distribution and flow of $\mathrm{CH}_{3} \mathrm{Hg}^{+}$ from the environment to the trophic chain is regulated by biogeochemical and physical ecological processes. Concentrations of mercury forms vary widely spatially in aquatic basins, and their distribution results from various factors facilitating methylation. The organic form of mercury, $\mathrm{CH}_{3} \mathrm{Hg}^{+}$, is a strong neurotoxin (SoRENSEN et al. 1999), and in fish it can make up as much as $95 \%$ of the content of $\mathrm{Hg}_{\text {total }}$ (Bloom 1992, Bank et al. 2007, Sunderland 2007). Considering the consequences that mercury has on human health, fish condition and environmental contamination, it is important to determine the concentration and distribution of its compounds in the tissues and organs of fish from different aquatic basins. Many articles in the literature address the $\mathrm{Hg}_{\text {total }}$ content in fish, while fewer data are available on $\mathrm{CH}_{3} \mathrm{Hg}^{+}$concentrations, and those that are available mainly refer to the $\mathrm{CH}_{3} \mathrm{Hg}^{+}$content of muscle tissues, because this parameter is used to assess risks to fish consumers' health (HARRIS et al. 2003, AMLUnd et al. 2007, LANG et al. 2017). Very limited information is available on the $\mathrm{Hg}_{\text {total }}$ and $\mathrm{CH}_{3} \mathrm{Hg}^{+}$content in other fish tissues or organs, and very few studies have reported on differences in the distribution of these compounds among fish tissues and organs (Onsanit et al. 2010, VisnJic-JEFTIC et al. 2010, ŁucZYŃSKA et al 2018). There are no data available on $\mathrm{CH}_{3} \mathrm{Hg}^{+}$levels in the tissues and organs of fish from Polish basins (the Baltic Sea, the Vistula Lagoon) or on levels of this element depending on species, tissues, organs, trophic chain position, food base, or region. A few studies have undertaken to explain the biotransfer and biomagnification of $\mathrm{Hg}_{\text {total }}$ and $\mathrm{CH}_{3} \mathrm{Hg}^{+}$in marine and freshwater ecosystems (Bowles et al. 2001, Kehring et al. 2001, Baeyens et al. 2003, Chen et al. 2008, 2009). Hammerschmidt and Fitzgerald (2006) indicate that the concentration of $\mathrm{CH}_{3} \mathrm{Hg}^{+}$in fish depends on their food base, the depths they inhabit in shallow and deep coastal waters, and their habitats. In 2016 and 2017, studies were undertaken to examine the organic and inorganic forms of mercury in tissues and organs of freshwater fish. Three fish species inhabiting the Vistula Lagoon and occupying different positions in the trophic chain were studied. The aim of the study was to determine the distribution of $\mathrm{Hg}_{\text {total }}, \mathrm{CH}_{3} \mathrm{Hg}^{+}$, and $\mathrm{Hg}_{\text {inorg }}$ in fish tissues and organs of pikeperch (Stizostedion lucioperca L.), bream (Aramis brama L.) and roach (Rutilus rutilus L.) intraspecific and interspecific differences in the concentrations of mercury forms, bioaccumulation in tissues, and biomagnification in the trophic chain. 


\section{MATERIALS AND METHODS}

\section{Study sampling}

The study material comprised fish caught in the Vistula Lagoon in 2015-2016. Specimens of three species (pikeperch, common bream, and common roach) of various ages (various lengths) were collected (Table 1). Assays were

Table 1

Biometric data of three fish species captured in the Vistula Lagoon

\begin{tabular}{|l|c|c|c|}
\hline \multicolumn{1}{|c|}{ Species } & $N$ & $\begin{array}{c}\text { Length (cm) } \\
x \pm \text { SD (range) }\end{array}$ & $\begin{array}{c}\text { Weight (g) } \\
x \pm \text { SD (range) }\end{array}$ \\
\hline Pikeperch (Stizostedion lucioperca) & 14 & $\begin{array}{c}50 \pm 7.8 \\
(31-57)\end{array}$ & $\begin{array}{c}1506 \pm 386 \\
(245-1710)\end{array}$ \\
\hline Bream (Aramis brama) & 10 & $\begin{array}{c}47.4 \pm 10.7 \\
(34-72)\end{array}$ & $\begin{array}{c}1194 \pm 749 \\
(606-3100)\end{array}$ \\
\hline Roach (Rutilus rutilus) & 10 & $26.1 \pm 5.7$ & $272.4 \pm 170$ \\
& $(23-32)$ & $(35.4-448)$ \\
\hline
\end{tabular}

performed on single specimens. Samples of muscle tissues, skin, gills, and internal organs (liver, heart, spleen, digestive tract, and gonads) were collected from each specimen. The muscle samples were homogenized, but the organs were analyzed in their entirety.

\section{Analysis of total mercury concentration}

Total mercury content was assayed with the cold vapour atomic absorption method in an AMA 254 mercury analyzer. The analyses were conducted according to the following procedure. Tissue samples of about $100 \mathrm{mg}$ were placed in the combustion chamber of the analyzer, where they were dried and then burned in oxygen atmosphere at a temperature of $600^{\circ} \mathrm{C}$. The measurements were conducted according to the following procedures: fish muscle tissue - drying time $70 \mathrm{~s}$, decomposition time $120 \mathrm{~s}$, waiting time $50 \mathrm{~s}$; fish liver tissue - drying time $100 \mathrm{~s}$, decomposition time $160 \mathrm{~s}$, waiting time $60 \mathrm{~s}$. Each series of analyses was preceded by measurements of mercury in reference materials of a similar matrix.

\section{Analysis of organic form of mercury concentration}

The content of the organic form of mercury was determined according to the method described by MAGGi et al. (2009), and Tong et al. (2012). In brief, the procedure was as follows: from 1 to $2.0 \mathrm{~g}$ of homogenized fish tissue was weighed out and placed in $50 \mathrm{ml}$ test tubes for centrifugation; $5 \mathrm{ml}$ of hydrochloric acid $(18 \% \mathrm{v} / \mathrm{v})$ and $5 \mathrm{ml}$ toluene were added; the test tubes were placed in an ultrasound water bath for $30 \mathrm{~min}$; then the test tubes were 
centrifuged for $30 \mathrm{~min}$ at $3500 \mathrm{rev} \mathrm{min}^{-1}$. The toluene layer was moved to $10 \mathrm{ml}$ test tubes, while $5 \mathrm{ml}$ of toluene was added to the remaining solution in the test tubes, which were again placed in an ultrasound bath for $30 \mathrm{~min}$, after which they were centrifuged again, as described above. After centrifugation, the upper layer of toluene was separated and added to the previously separated toluene, and $1 \mathrm{ml}$ of cysteine hydrochloride solution (1\% cysteine hydrochloride solution in a $20 \%$ sodium citrate solution) was added to the combined toluene layers, and this was placed in an ultrasound bath for $30 \mathrm{~min}$, and then centrifuged again, as described above. Before measurements, the upper layer of toluene was removed with a syringe. The content of $\mathrm{CH}_{3} \mathrm{Hg}^{+}$was measured in samples with an AMA 254 mercury analyzer.

\section{Measurement quality control}

The accuracy of the chemical analyses was verified using reference material before every measurement series. The following materials were used for $\mathrm{Hg}_{\text {total }}$ : TORT-2 Lobster Hepatopancreas (National Research Council of Canada) at a concentration of $\mathrm{Hg}_{\text {total }} 0.27 \pm 0.06 \mathrm{mg} \mathrm{kg}^{-1}$ and BCR-422 cod muscle (Joint Research Centre Institute for Materials and Measurements, Geel, Belgium) with a concentration of $\mathrm{Hg}_{\text {total }}$ of $0.559 \pm 0.016 \mathrm{mg} \mathrm{kg}^{-1}$. The following reference material was used for measurements of $\mathrm{CH}_{3} \mathrm{Hg}^{+}$: TORT-2 Lobster Hepatopancreas with a concentration of $\mathrm{CH}_{3} \mathrm{Hg}^{+}$ $0.152 \pm 0.013 \mathrm{mg} \mathrm{kg}{ }^{-1}$ and BCR-463 tuna fish (Joint Research Centre Institute for Materials and Measurements, Geel, Belgium) with a concentration of $\mathrm{CH}_{3} \mathrm{Hg}^{+} 3.04 \pm 0.16 \mathrm{mg} \mathrm{kg}^{-1}$. The recovery ranges were from 90 to $110 \%$. During validation, the limit of detection (MDLs) for $\mathrm{Hg}_{\text {total }}$ was $0.5 \mu \mathrm{g} \mathrm{kg} \mathrm{kg}^{-1}$ and for $\mathrm{CH}_{3} \mathrm{Hg}^{+}$it was $5 \mu \mathrm{g} \mathrm{kg}$. All samples were analyzed in duplicate. The results presented are arithmetic means with a standard deviation of less than $10 \%$.

\section{Calculations of the L:M coefficient}

The L:M coefficient was the quantifiable index that reflected inorganic mercury bioaccumulation and organic mercury biomagnification in fishes depending on their foraging strategies. The L:M coefficient refers to the ratio of $\mathrm{Hg}_{\text {inorg }}$ concentrations in the liver to $\mathrm{CH} 3 \mathrm{Hg}+$ concentrations in muscles. The liver:muscle ratio (L:M) was calculated considering the predominance

of the $\mathrm{Hg}_{\text {inorg }}$ form $\left(\mathrm{Hg}_{\text {inorg }}=\mathrm{Hg}_{\text {total }}-\mathrm{CH}_{3} \mathrm{Hg}^{+}\right)$in the hepatic tissue and of $\mathrm{CH}_{3} \mathrm{Hg}^{+}$in muscle (CIZDZIEL et al. 2003).

\section{Statistical analysis}

Statistica 8.0 software was used to perform descriptive statistics and regression analysis for all data. The mercury and methylmercury concentrations were tested for normality (Shapiro-Wilk test). The statistically significant differences in concentrations of $\mathrm{Hg}_{\text {total }}, \mathrm{CH}_{3} \mathrm{Hg}^{+}$, and the percent $\mathrm{CH}_{3} \mathrm{Hg}^{+}$ were established using parametric (ANOVA) or non-parametric (KRUSKAL 
WALLIS) tests. Relationships between $\mathrm{Hg}_{\text {total }}$ and $\mathrm{CH}_{3} \mathrm{Hg}^{+}$concentrations in the tissues and organs fish (nonparametric data) were tested using the Spearman's rank correlation test. Analysis of differences in concentrations $\mathrm{Hg}_{\text {total }}$, $\mathrm{CH}_{3} \mathrm{Hg}^{+}$and $\mathrm{Hg}_{\text {inorg }}$ between the different specimens from the ecological groups of fish (such as carnivorous, omnivorous, and herbivorous ones) were analyzed statistically with one-way ANOVA and the Tukey's post-hoc test. All null hypotheses were tested at the significance level of $p<0.05$

\section{RESULTS AND DISCUSSION}

\section{Intraspecific differences in $\mathrm{Hg}_{\text {total }}, \mathrm{CH}_{3} \mathrm{Hg}^{+}$, and $\mathrm{Hg}_{\text {inorg }}$ concentrations in tissues and organs of fish from the Vistula Lagoon, bioaccumulation}

The study results indicated that there were significant differences in mercury concentrations depending on fish species, tissues, and organs (Table 2). Pikeperch tissues contained the highest content $\mathrm{Hg}_{\text {total }}$, and high concentrations of it were detected in the muscle and liver of specimens of this species. The highest content mercury in roach and bream was also found in muscle, liver, and gastrointestinal tract. The $\mathrm{Hg}_{\text {total }}$ concentration gradation in pikeperch tissues and organs differed from those in the concentration tendencies in bream and roach. Generally, $\mathrm{Hg}_{\text {total }}$ dominated in the muscle of all three species, followed by concentrations in the pikeperch's liver. However, the high levels of $\mathrm{Hg}_{\text {total }}$ in the gastrointestinal tract of roach and bream accompanied by low levels of $\mathrm{CH}_{3} \mathrm{Hg}^{+}$in this organ should be underscored. The intraspecific concentration gradations for $\mathrm{Hg}_{\text {total }}$ in fish tissues and organs fish were as follows:

- pikeperch - muscle $>$ liver $>$ spleen $>$ heart $>$ gastrointestinal tract $>$ gonads > gills;

- common bream - muscle $>$ gastrointestinal tract $>$ liver $>$ kidney $>$ heart $>$ spleen $>$ gonads $>$ skin $>$ gills $>$ scales;

- common roach - muscle $>$ gastrointestinal tract $>$ liver $>$ skin $>$ heart $>$ kidney $>$ gills $>$ spleen $>$ gonads $>$ scales.

Similarly to those of $\mathrm{Hg}_{\text {total }}$, the concentrations of $\mathrm{CH}_{3} \mathrm{Hg}^{+}$in the tissues and organs of fish from the Vistula Lagoon were varied (Table 3). Muscles contained the highest content $\mathrm{CH}_{3} \mathrm{Hg}^{+}$, followed by concentrations of this element in the internal organs, gills, and skin.

The intraspecific concentration gradations for $\mathrm{CH}_{3} \mathrm{Hg}^{+}$in fish tissues and organs were as follows:

- pikeperch - muscle $>$ liver $>$ spleen $>$ gonads $>$ heart $>$ gastrointestinal tract > gills;

- common bream - muscle $>$ liver $>$ kidney, heart $>$ gastrointestinal tract $>$ spleen, gonads $>$ 


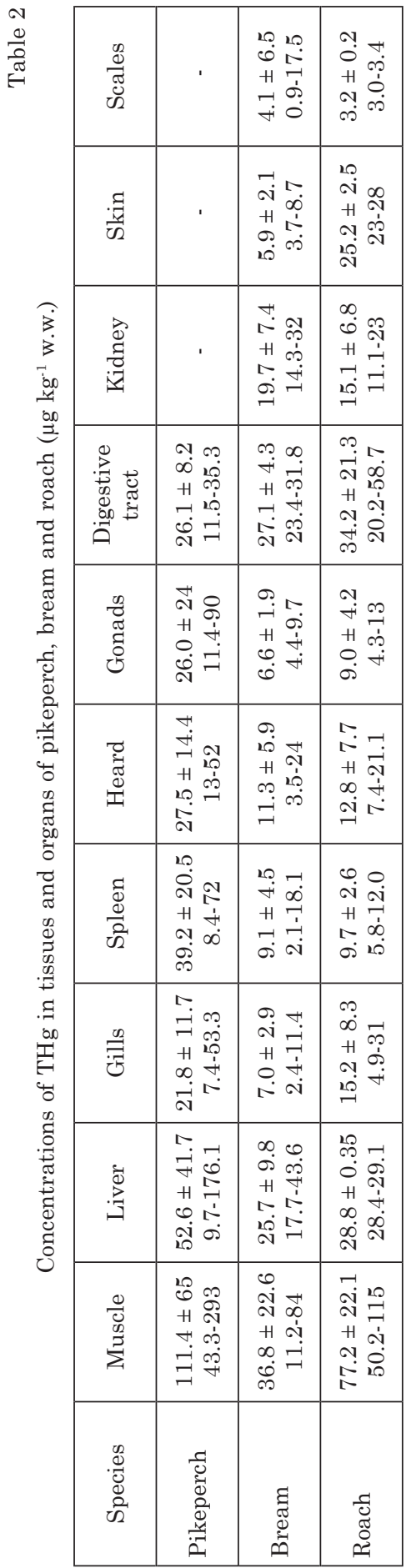

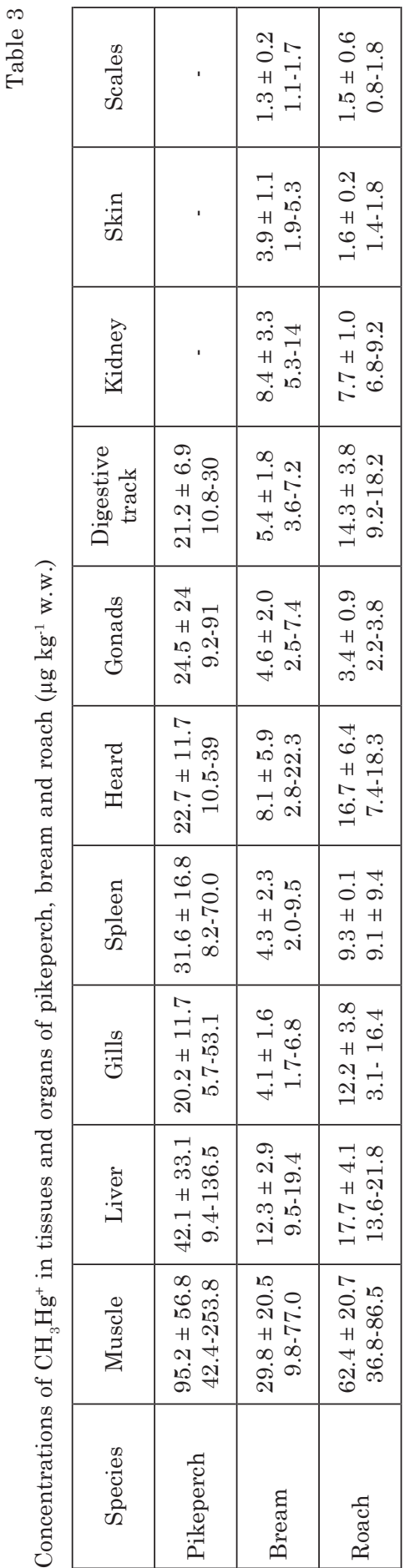


skin, gills > scales;

- common roach - muscle $>$ liver $>$ heart $>$ gastrointestinal tract $>$ gills $>$ spleen $>$ kidney $>$

gonads $>$ skin $>$ scales.

High $\mathrm{CH}_{3} \mathrm{Hg}^{+}$levels in fish muscles result from the affinity of this element to thiol groups in protein amino acids, such as cysteine (RUELAs-INZUNZA et al. 2003). Additionally, $\mathrm{CH}_{3} \mathrm{Hg}^{+}$is highly bioavailable, which means that fish almost completely assimilated it. $\mathrm{CH}_{3} \mathrm{Hg}^{+}$concentrations in internal organs of fish (liver, spleen, heart) were lower than those in muscles. This was because of the demethylation of organic mercury into inorganic compounds that occurred in internal organs. The $\mathrm{CH}_{3} \mathrm{Hg}^{+}$in pikeperch muscle comprised from 74.8 to $97.1 \% \mathrm{Hg}_{\text {total }}$, while in the liver its share ranged from 60.4 to $97.2 \%$ (Table 4). The share of this element in the heart, spleen, and gonads was also high at 75 to $99 \% \mathrm{Hg}_{\text {total }}$. Such high $\mathrm{CH}_{3} \mathrm{Hg}^{+}$content resulted from its transport through the trophic chain. Pikeperch is a predator situated at the highest position in the trophic chain. The share of organic mercury in pikeperch gills was also high and ranged from 75 to $99.5 \%$ of $\mathrm{Hg}_{\text {total }}$. The $\mathrm{CH}_{3} \mathrm{Hg}^{+}$contained in the fish gills came directly from the environment and was assimilated from water. Lower levels of organic mercury compounds occurred in roach and bream tissues and organs, but they were still varied. The share of $\mathrm{CH}_{3} \mathrm{Hg}^{+}$in the muscle of these fishes comprised about $80 \%$ of $\mathrm{Hg}_{\text {total }}$, while in the liver it was $63 \%$ of $\mathrm{Hg}_{\text {total }}$, and in the heart, spleen, and gonads it was up to $95 \%$ of $\mathrm{Hg}_{\text {total }}$ (Table 4).

Mercury also occurs in aquatic environments as inorganic compounds $\left(\mathrm{Hg}_{\text {inorg }}\right)$.

Table 5 presents the $\mathrm{Hg}_{\text {inorg }}$ content in fish tissues that was calculated as the difference between $\mathrm{Hg}_{\text {total }}$ and $\mathrm{CH}_{3} \mathrm{Hg}^{+}$. The concentrations of inorganic mercury forms differed from those of organic forms depending on the fish species and tissues. Pikeperch tissues contained the lowest levels of $\mathrm{Hg}_{\text {inorg }}$. Inorganic mercury compounds in the organs of these fishes (liver, heart, spleen, gastrointestinal tract, and gonads) comprised approximately $20 \%$ of $\mathrm{Hg}_{\text {total }}$. The $\mathrm{Hg}_{\text {inorg }}$ content in organs stems from bioaccumulation and the demethylation of organic mercury to inorganic forms (ZHANG et al. 2001). Low levels of $\mathrm{Hg}_{\text {inorg }}$ in pikeperch organs indicated that they accumulated it in small amounts and that the demethylation of $\mathrm{CH}_{3} \mathrm{Hg}^{+}$to $\mathrm{Hg}_{\text {inorg }}$ was not effective.

Fish accumulate inorganic mercury directly from the environment through the gills. The mean $\mathrm{Hg}_{\text {inorg }}$ content in pikeperch gills was $7.3 \%$ of $\mathrm{Hg}_{\text {total }}$ (Table 4). This indicated that pikeperch only assimilated $\mathrm{Hg}_{\text {inorg }}$ from water in the environment only to a slight degree, which was in contrast to bream and roach (41.8 and $24 \%$ of $\mathrm{Hg}_{\text {total }}$ ).

The $\mathrm{Hg}_{\text {inorg }}$ concentration gradations also differed in the other fish tissues and organs. Muscles contained the least $\mathrm{Hg}_{\text {inorg }}$ (approximately $20 \%$ of $\mathrm{Hg}_{\text {total }}$ ), but this form of mercury was noted in high levels in the gastrointestinal 
Table 4

Per cent $\mathrm{CH}_{3} \mathrm{Hg}^{+}$and $\mathrm{Hg}_{\text {inorg }}$ values in tissues and organs of pikeperch, bream and roach (\% of $\mathrm{THg})$

\begin{tabular}{|c|c|c|c|c|c|c|}
\hline \multirow{2}{*}{ Tissue/organ } & \multicolumn{2}{|c|}{ Pikeperch } & \multicolumn{2}{|c|}{ Bream } & \multicolumn{2}{|c|}{ Roach } \\
\hline & $\mathrm{CH}_{3} \mathrm{Hg}^{+}$ & $\mathrm{Hg}_{\text {inorg }}$ & $\mathrm{CH}_{3} \mathrm{Hg}^{+}$ & $\mathrm{Hg}_{\text {inorg }}$ & $\mathrm{CH}_{3} \mathrm{Hg}^{+}$ & $\mathrm{Hg}_{\text {inorg }}$ \\
\hline Muscle & $\begin{array}{c}85.7 \pm 7.7 \\
74.8-97.1\end{array}$ & $\begin{array}{c}14.4 \pm 7.6 \\
3.1-30.8\end{array}$ & $\begin{array}{c}79.3 \pm 7.7 \\
73-91.7\end{array}$ & $\begin{array}{c}22.7 \pm 9.2 \\
8.3-38.9\end{array}$ & $\begin{array}{c}80.0 \pm 8.7 \\
72.3-94\end{array}$ & $\begin{array}{c}20.0 \pm 8.7 \\
5.8-27.7\end{array}$ \\
\hline Liver & $\begin{array}{c}81.0 \pm 11.9 \\
60.4-97.2\end{array}$ & $\begin{array}{c}19.0 \pm 8 \\
2.8-43\end{array}$ & $\begin{array}{c}50.4 \pm 12.6 \\
24.3-66.9\end{array}$ & $\begin{array}{c}49.6 \pm 12.1 \\
33-76\end{array}$ & $\begin{array}{c}63.5 \pm 11.4 \\
52.1-74.9\end{array}$ & $\begin{array}{c}37 \pm 13 \\
25-52\end{array}$ \\
\hline Spleen & $\begin{array}{c}86.1 \pm 8.0 \\
74.7-97\end{array}$ & $\begin{array}{c}21.1 \pm 22 \\
10-47.4\end{array}$ & $\begin{array}{c}63.2 \pm 17 \\
45-95.2\end{array}$ & $\begin{array}{c}36.8 \pm 17 \\
4.8-55.1\end{array}$ & $\begin{array}{c}95.9 \pm 4.7 \\
89.2-97.3\end{array}$ & $\begin{array}{c}4.1 \pm 1.0 \\
3.2-5.0\end{array}$ \\
\hline Heard & $\begin{array}{c}86.3 \pm 7.6 \\
75.1-99.5\end{array}$ & $\begin{array}{l}20.0 \pm 18 \\
10.5-63.8\end{array}$ & $\begin{array}{c}68.7 \pm 22 \\
41-93.2\end{array}$ & $\begin{array}{c}33.0 \pm 22 \\
6.8-67.8\end{array}$ & $\begin{array}{c}67.2 \pm 14.4 \\
60.2-86.7\end{array}$ & $\begin{array}{c}8.7 \pm 2.6 \\
1.2-11.8\end{array}$ \\
\hline Digestive track & $\begin{array}{c}82.0 \pm 7.4 \\
71.5-93.9\end{array}$ & $\begin{array}{l}18.0 \pm 7.4 \\
6.1-28.5\end{array}$ & $\begin{array}{c}20 \pm 6.9 \\
15-30\end{array}$ & $\begin{array}{c}80.0 \pm 6.9 \\
70-85.2\end{array}$ & $\begin{array}{c}49 \pm 20 \\
31-77\end{array}$ & $\begin{array}{c}50.9 \pm 20 \\
22.8-69\end{array}$ \\
\hline Kidney & - & - & $\begin{array}{c}40.4 \pm 5.2 \\
37.1-7.5\end{array}$ & $\begin{array}{l}59.6 \pm 5.3 \\
52.2-62.9\end{array}$ & $\begin{array}{c}55.7 \pm 18 \\
29.6-65\end{array}$ & $\begin{array}{l}31.0 \pm 3.2 \\
27.4-35.1\end{array}$ \\
\hline Gonads & $\begin{array}{c}81.0 \pm 12.4 \\
54.4-99.5\end{array}$ & $\begin{array}{c}13.1 \pm 2.5 \\
0.5-9.6\end{array}$ & $\begin{array}{c}38.2 \pm 23.8 \\
25.8-87\end{array}$ & $\begin{array}{c}60.7 \pm 23.4 \\
13.4-74.2\end{array}$ & $\begin{array}{l}53 \pm 35.5 \\
17.5-88.4\end{array}$ & $\begin{array}{l}47 \pm 35.5 \\
11.6-82.5\end{array}$ \\
\hline Gills & $\begin{array}{c}91.4 \pm 9.1 \\
75-99.5\end{array}$ & $\begin{array}{c}7.3 \pm 6.7 \\
10-25.3\end{array}$ & $\begin{array}{c}56.7 \pm 13 \\
31-79.2\end{array}$ & $\begin{array}{c}41.8 \pm 12 \\
20.8-69\end{array}$ & $\begin{array}{c}70.3 \pm 11 \\
53-86.2\end{array}$ & $\begin{array}{c}24.0 \pm 17.3 \\
19-46.1\end{array}$ \\
\hline Skin & - & - & $\begin{array}{l}66.1 \pm 5.9 \\
56.4-73.3\end{array}$ & $\begin{array}{c}33.9 \pm 11.2 \\
19.6-42.2\end{array}$ & $\begin{array}{c}8.1 \pm 3.0 \\
5.1-12.2\end{array}$ & $\begin{array}{c}91.9 \pm 3 \\
88-95\end{array}$ \\
\hline Scales & - & - & $\begin{array}{c}83.4 \pm 14 \\
57.0-100\end{array}$ & $\begin{array}{c}68.3 \pm 14 \\
0-42.1\end{array}$ & $\begin{array}{c}45.3 \pm 13 \\
26-56.2\end{array}$ & $\begin{array}{c}54.7 \pm 13 \\
43.8-73\end{array}$ \\
\hline
\end{tabular}

tracts of bream and roach (approximately 80 and $51 \%$ of $\mathrm{Hg}_{\text {total }}$ ), which indicated that this form was taken up with food, and then accumulated in the internal organs. Thus, the $\mathrm{Hg}_{\text {inorg }}$ in the liver of bream and roach comprised 49.6 and $37 \%$ of $\mathrm{Hg}_{\text {total }}$, in the kidney it was 59.6 and $31 \%$ of $\mathrm{Hg}_{\text {total }}$, and in the gonads it was 60.7 and $47 \%$ of $\mathrm{Hg}_{\text {total }}$ (Table 5). These values confirmed the bioaccumulation of this form of mercury and indicated the intense $d$ emethylation process occurring in internal organs. The results of the study indicated three sources of $\mathrm{Hg}_{\text {inorg }}$ in fishes: 1) directly from the environment from water and sediments as confirmed by high $\mathrm{Hg}_{\text {inorg }}$ shares in gills and skin; 2) from food (high contents in the gastrointestinal tract); 3) through the demethylation of mercury from organic to inorganic forms $\left(\mathrm{Hg}_{\text {inorg }}\right.$ content in internal organs of fish).

The intraspecific $\mathrm{Hg}_{\text {inorg }}$ concentration gradation in tissues and organs varied and depended on fish species, as follows: 


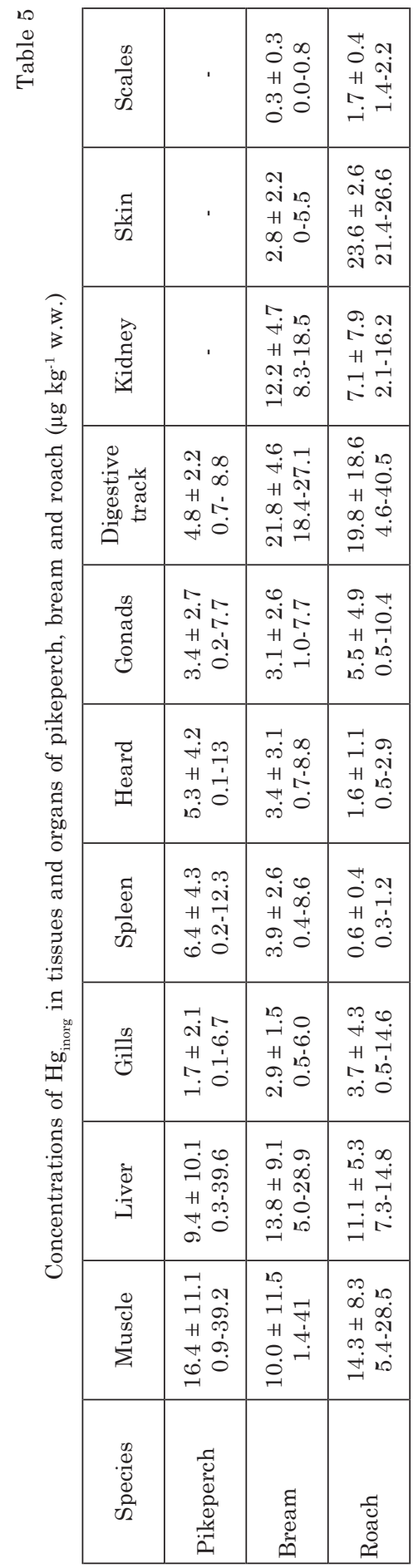


pikeperch - muscle $>$ liver $>$ spleen $>$ heart $>$ gastrointestinal tract $>$ gonads > gills;

common bream - gastrointestinal tract $>$ liver $>$ kidney $>$ muscle $>$ spleen $>$ heart $>$ gonads $>$ gills $>$ skin $>$ scales;

common roach - skin $>$ gastrointestinal tract $>$ muscle $>$ liver $>$ kidney $>$ gonads $>$ gills $>$ scales $>$ heart.

\section{Interspecific differences in $\mathrm{Hg}_{\text {total }}, \mathrm{CH}_{3} \mathrm{Hg}^{+}$, and $\mathrm{Hg}_{\text {inorg }}$ concentrations in tissues and organs of fishes from the Vistula Lagoon and biomagnification in the trophic chain}

All mercury forms bioaccumulate, but $\mathrm{CH}_{3} \mathrm{Hg}^{+}$also biomagnifies in aquatic food chains to varying degrees. Biomagnification is defined as gradually increasing concentrations of this metal along the trophic food chain from lower trophic levels (prey) to the highest levels (predator). Biomagnification along the trophic chain is the primary route of mercury accumulation in aquatic organisms and it is associated with the life strategies of fishes and the tropic position from which their food comes (Turner, Swick 1983, BARWick, MAHER 2003). Mercury assays in fish species from different trophic positions can provide information about bioaccumulation and biomagnification, which can occur even when the species examined do not feed directly on each other. (KeHRing et al. 2009, 2010, Fu et al. 2010).

Studies of $\mathrm{Hg}_{\text {total }}, \mathrm{CH}_{3} \mathrm{Hg}^{+}$, and $\mathrm{Hg}_{\text {inorg }}$ concentrations were performed on fish species (pikeperch, roach, and bream) from different positions in the trophic chain and with different foraging strategies. The type of food consumed greatly influenced the amount of mercury assimilated by fish organisms, because there is a marked difference among the concentrations of this element in microplankton, mesozooplankton, and fish.

The results of the study indicated that pikeperch tissues contained the highest concentration $\mathrm{Hg}_{\text {total }}$ and $\mathrm{CH}_{3} \mathrm{Hg}^{+}$. Organic mercury dominated in muscle and liver at 85.7 and $81 \%$ of $\mathrm{Hg}_{\text {total }}$ (Table 4), and it also occurred in internal organs at high levels $\left(80 \%\right.$ of $\left.\mathrm{Hg}_{\text {total }}\right)$. The high $\mathrm{CH}_{3} \mathrm{Hg}^{+}$concentrations in the pikeperch's gastrointestinal tract indicated that it had been ingested with food. Pikeperch are predators that feed primarily on small fishes. Whole small fishes were found in the gastrointestinal tracts of most of the pikeperch examined, and they were the source of $\mathrm{CH}_{3} \mathrm{Hg}^{+}$. Previous studies report high $\mathrm{CH}_{3} \mathrm{Hg}^{+}$concentrations in fish muscle (POLAK-JUszcZAK 2017). There is a significant difference between the concentrations of organic mercury in fishes, microplankton, and mesozooplankton (KWAŚNIAK, FALKOWSKA 2012). Increased concentrations of organic mercury in fish muscle tissues occurred along with increasing shares of animal food in the diet, while increased concentrations of inorganic mercury were noted with the higher consumption of food from lower trophic levels.

Common bream and common roach feed on organisms from lower positions in the trophic chain. Bream are typical benthivores that feed on ani- 
mals inhabiting the bottom sediments, and they can suck prey out of the mud, while juveniles feed on zooplankton. Roach consume both vegetable and animal food, and they switch between these types of food several times. Roach fry feed on planktonic crustaceans, and older specimens feed on benthic foods, including crustaceans, smaller larval insects, algae, and other plants. At lengths of approximately $20 \mathrm{~cm}$ they begin to feed on molluscs, mainly zebra mussel. Significant differences were confirmed in $\mathrm{CH}_{3} \mathrm{Hg}^{+}$and $\mathrm{Hg}_{\text {inorg }}$ concentrations in the gastrointestinal tracts of pikeperch, roach, and bream (Table 4). Concentrations of $\mathrm{CH}_{3} \mathrm{Hg}^{+}$in the pikeperch's gastrointestinal tract were significantly higher than those in bream and roach.

However, an opposite trend was noted in $\mathrm{Hg}_{\text {inorg }}$ concentrations. The inorganic form of mercury dominated in bream and roach gastrointestinal tracts, while significantly less was noted in pikeperch stomachs. The high $\mathrm{CH}_{3} \mathrm{Hg}^{+}$ content in pikeperch gastrointestinal tracts and the high $\mathrm{Hg}_{\text {inorg }}$ content in roach and bream stomachs were linked with feed, which included organisms from different positions in the trophic chain (fishes, phytoplankton, and zooplankton). As anticipated, specimens of piscivorous species (pikeperch) had higher $\mathrm{CH}_{3} \mathrm{Hg}^{+}$levels, while fish that consumed phytoplankton and zooplankton (roach) had higher $\mathrm{Hg}_{\text {inorg }}$ levels. Bream tends to inhabit the bottom layers of water and feeds by digging through sediment in search of food. Consequently, bream may have prolonged time of contact with sediment, resulting in high accumulation of $\mathrm{Hg}$ in the forms of $\mathrm{Hg}$ (II). Consequently, both Hg-contained water and sediment could be potential exposure sources to freshwater bream species (CHENG et al. 2016). Similar observations were described by ŁuczYŃsKA et al. (2016) and Li et al. (2009). The foraging environment impacts mercury concentrations in fish tissues. The first organ exposed to mercury suspended in the water and sediments are the gills. Pikeperch gills contained $20.2 \mu \mathrm{g} \mathrm{CH}_{3} \mathrm{Hg}^{+} \mathrm{kg}^{-1}$, which comprised $91 \%$ of $\mathrm{Hg}_{\text {total }}$ (Tables 3, 4). The content and share of $\mathrm{CH}_{3} \mathrm{Hg}^{+}$in $\mathrm{Hg}_{\text {total }}$ were significantly lower in the gills of bream and roach at 56.7 and $70.3 \%$ (Table 4). The opposite was true of $\mathrm{Hg}_{\text {inore }}$ concentrations. The inorganic mercury in the gills of bream and roach was 41.8 and $24 \%$ of $\mathrm{Hg}_{\text {total }}$, while in those of pikeperch it was $7.3 \%$ (Table 4 ).

Concentrations of mercury forms in the freshwater fish species examined varied depending on the species: $\mathrm{Hg}_{\text {total }}$ - pikeperch $>$ common roach $>$ common bream; $\mathrm{CH}_{3} \mathrm{Hg}^{+}-$pikeperch $>$common roach > common bream; $\mathrm{Hg}_{\text {inorg }}-$ common bream $>$ common roach $>$ pikeperch.

The values of the L:M coefficient varied depending on species and its position in the trophic chain. The highest values were calculated for bream at a mean of 0.577 within a range of 0.297 - 1.016 (Table 6).

Significantly lower values of this coefficient were noted in roach at 0.222 (within a range of $0.124-0.319$ ), and the lowest were for pikeperch at 0.107 (within a range of 0.007 to 0.291 ). The value of the L:M coefficient was linked with the fish's food and indirectly with the trophic chain. High values 
Values of the L:M coefficient for pikeperch, bream and roach

\begin{tabular}{|l|c|c|}
\hline \multicolumn{1}{|c|}{ Species } & $\begin{array}{c}\text { L:M } \\
\text { average }\end{array}$ & $\begin{array}{c}\text { L:M } \\
\text { range }\end{array}$ \\
\hline Pikeperch & 0.107 & $0.007-0.291$ \\
\hline Bream & 0.577 & $0.297-1.016$ \\
\hline Roach & 0.222 & $0.124-0.319$ \\
\hline
\end{tabular}

of the $\mathrm{L}: \mathrm{M}$ coefficient indicated increased concentrations of $\mathrm{Hg}_{\text {inorg }}$ in the liver. In the current study, the highest values of the L:M coefficient were determined in bream (0.297 - 1.016). Bream is typically benthophagous, and it feeds on organisms inhabiting the bottom sediments that contain less $\mathrm{CH}_{3} \mathrm{Hg}^{+}$in comparison to $\mathrm{Hg}_{\text {inorg }}$. High values of the $\mathrm{L}: \mathrm{M}$ coefficient in bream indicated the bioaccumulation of $\mathrm{Hg}_{\text {inorg }}$ in the liver and intensive demethylation in this organ. Interpretations regarding roach were similar even though the values of the L:M coefficient were lower. However, low values of the L:M coefficient indicated increased $\mathrm{CH}_{3} \mathrm{Hg}^{+}$in fish muscles. Low values of the L:M coefficient for pikeperch (mean 0.107 within a range of 0.007 - 0.291 ) were associated with the large amounts of $\mathrm{CH}_{3} \mathrm{Hg}^{+}$ingested with food. Low values of the $\mathrm{L}: \mathrm{M}$ coefficient also indicated that the demethylation of $\mathrm{CH}_{3} \mathrm{Hg}^{+}$ to $\mathrm{Hg}_{\text {inorg }}$ was inefficient in the liver tissues of pikeperch.

\section{CONCLUSIONS}

The results of the study indicated the following intraspecific and interspecific differences in $\mathrm{Hg}_{\text {total }}, \mathrm{CH}_{3} \mathrm{Hg}^{+}$, and $\mathrm{Hg}_{\text {inorg }}$ concentrations in fish tissues and organs:

- fish muscle was the tissue with the highest concentration of $\mathrm{CH}_{3} \mathrm{Hg}^{+}$, while the liver contained the highest concentration of $\mathrm{Hg}_{\text {inorg }}$;

- high $\mathrm{Hg}_{\text {inorg }}$ concentrations in the liver stemmed from bioaccumulation and from demethylation process of organic mercury forms to inorganic forms;

- the organic form of mercury dominated in piscivourus fish;

- inorganic mercury forms dominated in fishes (common roach, common bream) from lower positions in the trophic chain, that feed on phytoplankton, zooplankton and benthos;

- $\mathrm{CH}_{3} \mathrm{Hg}^{+}$and $\mathrm{Hg}_{\text {inorg }}$ concentrations in fish tissues and organs depended on the type of food consumed and its bioavailability in the environment, which was confirmed by quantifiable differences in the values of the L:M coefficient $\left(\mathrm{Hg}_{\text {inorg }}\right.$ in liver : $\mathrm{CH}_{3} \mathrm{Hg}^{+}$in muscles); 
- food was the main source of mercury accumulated in fish tissues;

- the distribution of inorganic and organic mercury in the tissues and organs of fish was linked with species and their foraging habits and position on the trophic chain.

\section{REFERENCE}

Amlund h., Lundebye A.K., Berntssen M.H.G. 2007. Accumulation and elimination of methylmercury in Atlantic cod (Gadus morhua L.) following dietary exposure. Aquat Toxicol, 83: 323-330. https://doi.org/10.1016/j.aquatox.2007.05.008

Baeyens W., Leermakers M., Papina T., Saprykin A., Brion N., Noyen J., Gieter M. D., Elskens M., GoEYENS L. 2003. Bioconcentration and biomagnification of mercury and methylmercury in North Sea and Scheldt Estuary fish. Arch Environ C Tox, 45: 498-508. DOI: 10.1007/ /s00244-003-2136-4

Banku M.S., Chesney E., Shine J.P., MaAge A., Senn D.B. 2007. Mercury bio accumulation and trophic transfer in sympatric snapper species from the Gulf of Mexico. Ecol Appl, 17: 2100-2110. https://doi.org/10.1890/06-1422.1

BARWick M., MAHER W. 2003. Biotransference and biomagnification of selenium copper, cadmium, zinc, arsenic and lead in a temperate seagrass ecosystem from Lake Macquarie Estuary, NSW, Australia. Mar Environ Res, 56(4): 471-502. DOI: 10.1016/S0141-1136(03)00028-X

Bloom N.S. 1992. On the chemical form of mercury in edible fish and marine invertebrate tissue. Can J Fish Aquat Sci, 49: 1010-1017. DOI:org/10.1139/f92-113

Bowles K.C., Apte S.C., Maher W.A., Kawei M., Smith R. 2001. Bioaccumulation and biomagnifications of mercury in Lake Murray, Papua New Guinea. Can J Fish Aquat Sci, 58: 888-897. DOI: $10.1139 /$ cjfas-58-5-888

Chen C., Amirbahman A., Fisher N., Harding G., Lamborg C., Nacci D., Taylor D. 2008. Methylmercury in marine ecosystems: spatial patterns and processes of production, bioaccumulation, and biomagnification. EcoHealth, 5: 399-408. DOI: 10.1007/s10393-008-0201-1

Chen C.Y., Dionne M., Mayes B.M., Ward D.M., Sturup S., Jackson B.P. 2009. Mercury bioavailability and bioaccumulation in estuarine food webs in the Gulf of Marine. Environ Sci Technol, 43: 1804-1810. DOI: 10.1021/es8017122

Cheng Y-H., Lin Y-J., You S-H., Yang Y.F., How C.M., Tseng Y.T., Chen W.Y., Liao C.M. 2016. Assessing exposure risks for freshwater tilapia species posed by mercury and methylmercury. Ecotoxicology, 25: 1181-1193. DOI 10.1007/s10646-016-1672-4

Cizdziel J., Hinners T., Cross C., Pollard J. 2003. Distribution of mercury in the tissues of five species of freshwater fish from Lake Mead, USA. J Envrion Monit, 5: 802-807. DOI: 10.1039/ /b307641p

Fu J., Wang Y., Zhou Q., Jiang G. 2010. Trophic transfer of mercury and methylmercury in an aquatic ecosystem impacted by municipal sewage effluents in Beijing, China. J Environ Sci, 22(8): 1189-1194. DOI: 10.1016/S1001-0742(09)60237-0

Hammerschmidt C.R., Fitzgerald W.F. 2006. Bioaccumulation and trophic transfer of methylmercury in Long Island Sound. Arch Environ C Tox, 51: 416-424. DOI: 10.1007/s00244$-005-0265-7$

Harris H., Pickering I., George G. 2003. The chemical form of mercury in fish. Science 301, 1203. Available 09.03.2018 https://www.sciencemag.org Science vol. 301

Kehring H.A., Costa M., Moreira I., Malm O. 2001. Methylmercury and total mercury in estuarine organisms from Rio de Janeiro, Brazil. Environ Sci Pollut Res, 8(4): 275-279. DOI: http://dx.doi.orq/10.1065/esDr2001.08.073

Kehring H.A., Seixas T., Palermo E., Seixas T.G., Palermo E.A., Baeta A.P. Castelo-Branco Ch.W., Malm O., Moreira I. 2009. The relationships between mercury and selenium in plankton 
and fish from a tropical food web. Environ Sci Pollut Res, 16: 10- 24. DOI: 10.1007/s11356-008-0038-8

Kehring H.A., Seixas T.G., Baetalm O., Moreira I. . 2010. Inorganic and methylmercury: Do they transfer along a tropical coastal food web?. Mar Poll Bull, 60: 2350-2356. DOI: 10.1016/j. marpolbul.2010.08.010

KWAŚNIAK J., FaLKowsKa L. 2012. Mercury distribution in muscles and internal organs of the juvenile and adult Baltic cod (Gadus morrhua callarias Linnaeus, 1758). Oceanol Hydrobiol St, 41(2): 65-71. DOI: 10.2478/s13545-012-0018-y

Lang T., Kruse R., Haarich M., Wosniok W. 2017. Mercury species in dab (Limanda limanda) from the North Sea, Baltic Sea and Icelandic waters in relation to host-specific variables. Mar Environ Res, 124: 32-40. DOI: 10.1016/j.marenvres.2016.03.001

Li S., Zhou L. Wang H., Liang Y., Hu J., Chang J. 2009. Feeding habits and habitats preferences affecting mercury bioaccumulation in 37 subtropical fish species from Wujiang River, China. Ecotoxicology, 18: 204-210. DOI: 10.1007/s10646-008-0289-7

ŁuczyŃSKa J., ŁuczyŃski M.J., PAszczyK B. 2016. Assessment of mercury in muscles, liver and gills of marine and freshwater fish. J Elem, 21(1): 113-129. DOI: 10.5601/jelem.2015.20.2.879

Łuczyńska J., Paszczyk B., Łuczyński M.J. 2018. Fish as a bioindicator of heavy metals pollution in aquatic ecosystem of Pluszne Lake, Poland, and risk assessment for consumer's health. Ecotoxicol Environ Saf, 153: 60-67. DOI:10.1016/j.ecoenv.2018.01.057

Maggi C., Berducci M.T., Bianchi J., Giani M., Campenelda L. 2009. Methylmercury determination in marine sediment and organisms by direct mercury analyzer. Anal Chim Acta, 641: 32-36. DOI: 10.1016/j.aca.2009.03.033

Onsanit S., Ke C., Wang K.J., Wang W.X. 2010. Trace elements in two marine fish cultured in fish cages in Fujian province, China. Environ Pollut, 158: 1334-342. DOI: 10.1016/j. envpol.2010.01.012

Polak-Juszczak L. 2017. Methylmercury in fish from the southern Baltic Sea and coastal lagoons as a function of species, size and region. Toxicol Ind Health, 33(6): 503-511. DOI: 10.1177/ /0748233716685647

Ruelas-Inzunza J.R., Horvat M., Perez-Cortes H., Paez-Osuna F. 2003. Methylmercury and total mercury distribution in tissues of gray whales (Eschrichtius robustus) and spinner dolphins (Stenella longirostris) stranded along the lower Gulf of California. Mexico. Cienc, 29(1): 1-8.

Sorensen N., Murata K., Budtz-Jorgensen E., Weine P., Grandjean P. 1999. Prenatal methylmercury exposure as a cardiovascular risk factor at seven years of age. Epidemiology, 10: 370-375.

SunderLand E.M. 2007. Mercury exposure from domestic and imported estuarine and marine fish in the U.S. seafood market. Environ Health Persp, 115: 235-242. DOI: 10.1289/ehp.9377

Tong Y.D., Zhang W., Hu X.D., Ou L.B., Hu D., Yang T.J., Wei w., Wang X.J. 2012. Model description of trophodynamic behavior of methylmercury in marine aquatic system. Environ Pollut, 166: 89-97. https://doi.org/10.1016/j.envpol.2012.03.007

Turner M.A., Swick A.L. 1983. The English Wabigoon River System: interaction between mercury and selenium accumulated from waterborne and dietary sources by northern pike. Can J Fish Aquat Sci, 40: 2241-2250. https://doi.org/10.1139/f83-260

Zhang X., Naidu A.S., Kelley J., Jewett S.C., Dasher D., Duffy L.K. 2001. Baseline concentrations of total and methyl-mercury in salmon returning via the Bering Sea (1999-2000). Mar Pollut Bull, 42: 993-997. DOI: 10.1021/acs.est.8b01299

Visnjic-Jeftic Z., Jaric I., Jovanovic L., Skoric S., Smederevac-Lalic M., Nikcevic M., Lenhardt M. 2010. Heavy metal and trace element accumulation in muscle, liver and gills of the Pontic shad (Alosa immaculata Bennet 1835) from the Danube River (Serbia). Microchem J, 95: 341-344. DOI: 10.1016/j.microc.2010.02.004 